JAN PIETRZYKOWSKI SDB* - WARSZAWA

\title{
ARS PRAEDICANDI. WYBITNI KAZNODZIEJE KONWENTU KRAŚNICKIEGO
}

Kaznodziejstwo w Polsce w okresie średniowiecza przebiegało podobnie jak historia kaznodziejstwa w krajach zachodnich, z tą różnicą, że nasze przepowiadanie Słowa Bożego obficie czerpało z obcych źródeł i rozwijało się w odmiennym rytmie dziejowym. Rozwój kaznodziejstwa w Kościele katolickim jest wyraźnie dostrzegalny dopiero po Soborze Laterańskim IV (1215). Na mocy 10. dekretu De predicatoribus instituendis (o ustanowieniu kaznodziejów) tegoż soboru powszechnego, dopuszczono stosowanie języków miejscowych w kazaniach do ludu i zalecono powołanie specjalnego urzędu kaznodziei przy kościołach katedralnych i klasztornych. Troska o odnowę i właściwy poziom kaznodziejstwa skłoniła św. Dominika do założenia w 1216 roku zakonu kaznodziejskiego, a był nim Ordo Predicatorum - dominikanów. Wkrótce pozycja kaznodziei uzyskała uprzywilejowane miejsce w społeczeństwie średniowiecznym. Z funkcji kapłańskich przepowiadanie uzyskuje najwyższą rangę, ponieważ wymaga odpowiednich kwalifikacji intelektualnych, oratorskich i duchowych ${ }^{1}$. W polskim ustawodawstwie synodalnym rozporządzenie o kaznodziejstwie znajduje się w statutach prowincjonalnych synodu łęczyckiego z 1285 roku, który odbył się pod przewodnictwem metropolity gnieźnieńskiego arcybiskupa Jakuba Swinki. Zalecał on, żeby wierni podczas niedzielnej sumy odmawiali pacierz, a ,jeśli byliby biegli [kapłani], niechaj wykładają Ewangelię, aby wierni strzegli się od złego, a czynili dobrze"2. Problematyka ta była podejmowana także na późniejszych synodach diecezjalnych. Biskup krakowski Nanker w 1320 roku polecił odmawiać i wyjaśniać teksty pacierza oraz ,jeśliby któremukolwiek zostało udzielone zezwolenie

* Jan Pietrzykowski SDB - dr hab. historii Kościoła; prof. w Instytucie Historii na Wydziale Nauk Historycznych i Społecznych UKSW; kierownik Zakładu Badań nad Historią Kościoła w Średniowieczu; e-mail: jan_pie@poczta.onet.pl

${ }^{1}$ Dokumenty Soborów Powszechnych, oprac. A. Baron, H. Pietras, t. 2, Kraków 2003, s. 244247; J. Wolny, Kaznodziejstwo, w: Dzieje teologii katolickiej w Polsce, t. 1: Średniowiecze, red. M. Rechowicz, Lublin 1974, s. 276.

${ }^{2}$ I. Subera, Synody prowincjonalne arcybiskupów gnieźnieńskich, Warszawa 1971, s.58. 
na wyjaśnienie Ewangelii w języku ludowym, to niechaj się pilnie do tego przykładają"3.

Do społeczności uniwersyteckiej kazania w języku łacińskim głosili jego członkowie, profesorowie uniwersytetu. Ponadto ze względu na odpowiednie przygotowanie byli oni dość często angażowani do prowadzenia działalności kaznodziejskiej w katedrach, kolegiatach i kościołach miejskich. Księżom wiejskim i słabo wykształconym zalecano uczestnictwo w kazaniach „uczonych” w celu dokształcania się. Obok kazania uczonego (sermo) w formie wykładu, uprawianego głównie w katedrach i uniwersytetach, były głoszone kazania popularne, przeznaczone dla ogółu wiernych. Duży wkład w nauczanie ludu, niezależnie od jego stopnia wykształcenia, miały nowe zakony żebracze. Trzy środowiska kaznodziejskie: uniwersyteckie, katedralne (kolegiackie) i zakonne na trwałe wpisały się w historię przygotowania kaznodziejów oraz w tematykę i charakter kazań ${ }^{4}$.

Wiernym bez specjalnego przygotowania intelektualnego księża zakonni i diecezjalni głosili nauki popularne, nawiązujące do tradycji homilii, preferujący łatwy i obrazowy wykład nauki, wyzwalający emocje i wyobraźnię słuchacza. Do tego zadania byli zapraszali też księża zakonni i dzięki temu zakony żebracze wkraczały w kaznodziejstwo parafialne. W posługę głoszenia Słowa Bożego angażowali się także duchowni z zakonów i kongregacji kanonickich o starszej metryce, jak: bożogrobcy, norbertanie, kanonicy regularni i inni, którzy realizowali swoje posłannictwo w Kościele także poprzez prowadzenie duszpasterstwa parafialnego. Wyselekcjonowani kaznodzieje głosili kazania nie tylko w głównych kościołach zakonnych, opackich, prepozyturach, przy których były parafie, ale zapraszano ich okazjonalnie do okolicznych świątyń ${ }^{5}$.

Z przełomu XIII i XIV wieku zachowały się polskie teksty Kazań Świętokrzyskich, które są zabytkiem nie tylko rodzimej sztuki homiletycznej, ale także średniowiecznego języka ojczystego. Przechowywane w klasztornych archiwach i bibliotekach kodeksy i zbiory kazań potwierdzają posługiwanie się językiem ludowych w przekazywaniu wiernym przez księży prawd wiary i moralności. Jednak kaznodziejstwo w Polsce rozwinęło się dopiero w XV wieku. Zdecydowany wpływ miał zwiększający się udział duchownych w studiach wyższych na Uniwersytecie Karola w Pradze i w odnowionym Uniwersytecie Krakowskim (Jagiellońskim) oraz powstanie nowego dynamicznego odłamu franciszkańskiego, Braci Mniejszych Obserwantów, nazywanych w Polsce popularnie bernardynami. W porównaniu z okresem wcześniejszym, w większym stopniu pojawia się kaznodziejstwo w języku narodowym nie tylko w świątyniach parafialnych, ale w katedrach, kolegiatach i głównych kościołach miejskich. Zdecydowanie poszerza się zakres piśmiennictwa kaznodziejskiego co do rozpiętości tematycznej i ilości

${ }^{3}$ Najstarsze statuty synodalne krakowskie biskupa Nankera z 2 października 1320 r., wyd. J. Fijałek, Kraków 1915, s. 27; Z. Kliszko, Przepisy synodalne w Polsce średniowiecznej o kaznodziejstwie, „Studia Theologica Varsaviensia”, 13 (1975) nr 1, s. 128-131.

${ }^{4}$ Wolny, Kaznodziejstwo, s. 275-277; W. Pazera, Kaznodziejstwo w Polsce od poczatku do końca epoki baroku, Częstochowa 1999, s. 20-26.

${ }^{5} \mathrm{~K}$. Panuś, Kaznodziejstwo w katedrze krakowskiej, cz. 1: Od początków do czasów rozbiorów, Kraków 1995, s. 35-38. 
autorów. Na użytek duszpasterzy powstają kolekcje pomocy kaznodziejskich pisanych przez rodzimych twórców. Zachowane zbiory kazań dotyczą różnorodnej problematyki: dekalogu, grzechów głównych, sakramentów, rzeczy ostatecznych, zagadnień moralnych i katechizmowych ${ }^{6}$.

Biblioteki katedralne, kolegiackie, a nawet parafialne wyposażono w księgozbiory kaznodziejskie. Ten dział często zawierał najwięcej pozycji i z pewnością był najczęściej wykorzystywany. Przeważnie na jego zasób składały się kazania roczne, świąteczne, niedzielne i wielkopostne, będące piętnastowiecznymi odpisami. Skład księgozbioru nie odbiegał w zasadzie od wymagań stawianych duchowieństwu diecezjalnemu. Na szczególną uwagę w dziedzinie posiadania cennych zbiorów bibliotecznych zasługują kongregacje kanoników, zajmujące się także prowadzeniem duszpasterstwa parafialnego i wychowaniem oraz wykształceniem księży. Spośród nich, poza bożogrobcami w Miechowie, generalnie pierwsze miejsce przypada kanonikom regularnym św. Augustyna. Ich opactwa i klasztory na ziemiach polskich posiadały cenne księgozbiory o różnorodnej tematyce, w tym kaznodziejskiej. Zgodnie z zaleceniem papieża Benedykta XII z roku 1339, kanonicy regularni pielęgnowali teologię, prawo i biblioteki, będące zapleczem ich szkół i pracy kaznodziejskiej. Na przykładzie bogatego katalogu księgozbioru żagańskiego można wyciągać daleko idące wnioski o poziomie szkoły klasztornej i ambicjach naukowych samych zakonników. Nowością w wykazie książek były także pozycje podręcznikowe, traktaty antyhusyckie i dzieła pisarzy mistycznych. Ponadto, w znaczniejszych opactwach i prepozyturach nie ograniczano się tylko do gromadzenia i przechowywania rękopisów, ale w miejscowych skryptoriach też przepisywano, popularyzując, kazania uznanych i popularnych kaznodziejów. Znacząca literatura kaznodziejska gromadzona, przechowywana i aktualizowana w konwentach kanoników regularnych laterańskich, a także prywatne zbiory księży potwierdzają ważność tej dziedziny pracy i dobre przygotowanie księży w dziedzinie kaznodziejstwa. Co więcej, zasób bibliotek, jak i poziom szkół prowadzonych przy konwentach poświadczają umiłowanie nauki przez kanoników regularnych ${ }^{7}$.

Wśród prepozytur kongregacji krakowskiej wyróżniał się konwent w Kraśni$\mathrm{ku}$. Zakonnicy prowadzili tam prawie wszystkie dzieła wchodzące w skład ich posłannictwa. Poza miejscową parafią, kanonicy regularni słynęli z dobrze prosperującej szkoły, wysokiego poziomu skryptorium i wzorowego szpitala. Na potrzeby zakonu zorganizowano w Kraśniku nowicjat i seminarium duchowne. O poziomie intelektualnym zakonników świadczyła biblioteka bogato zaopatrzona w kodeksy i inkunabuły oraz starodruki. Zbiory kazań stanowiły najliczniejszą grupę tema-

${ }^{6}$ J. Ziomek, Postylla, w: Renesans, Warszawa 1998, s. 127-232; Pazera, Kaznodziejstwo w Polsce, s. 55-62.

${ }^{7}$ M. Rechowicz, Początki i rozwój kultury scholastycznej (do końca XIV wieku), w: Dzieje teologii katolickiej w Polsce, t. 1, s. 64, 70-71; R. Skrzyniarz, Zbiory kazań w polskich księgozbiorach okresu średniowiecza, „Archiwa, Biblioteki i Muzea Kościelne”, 70 (1998) s. 249-253; E. Zielińska, Kultura intelektualna kanoników regularnych z klasztoru w Kraśniku w latach 1469-1563, Lublin 2002, s. 30; K. Panuś, Historia kaznodziejstwa, Kraków 2007, s. 175; K. Latak, S. Nalbach, Ze studiów nad kultura umystowa kanoników regularnych krakowskiej prepozytury Bożego Ciała w XV i XVI wieku, Kraków 2009, s. 200-204. 
tyczną tej biblioteki, a ich teksty znajdują się w 16 kodeksach rękopiśmiennych. W grupie kazań dominują liczebnie autorzy dominikańscy i franciszkańscy. Przez ten konwent przeszło ponad 70. najwybitniejszych kanoników regularnych w Polsce i to w różnych dziedzinach: naukowej, kaznodziejskiej, muzycznej, ascetycznej, organizacyjnej ${ }^{8}$.

W przeciwieństwie do obecnej praktyki, kiedy kazania głosi prawie każdy ksiądz zakonny, w przeszłości - od średniowiecza aż do prawie połowy XIX wie$\mathrm{ku}$ - mogli je głosić tylko wyznaczeni kapłani ${ }^{9}$. Wypada nadmienić, że kaznodziejstwo zaliczano do wyższych form nauczania religijnego. Kanoników pracujących jako kaznodzieje zaliczano do elity kongregacji. Ich pozycję formalnie wyznaczała reguła zakonna i statuty opactwa czy prepozytury. Rozporządzenia te określały zasady, według których byli nominowani kandydaci do pełnienia posługi kaznodziei. Ważnym etapem decydującym o wyborze księży zakonnych na przyszłych kaznodziejów był proces kształcenia, nienaganna postawa moralna, dobry głos, ponieważ przekaz werbalny należał do podstawowych narzędzi kaznodziei. Dodatkowo obligowano ich do posiadania jurysdykcji do spowiadania wiernych. Kaznodziejom powierzano obowiązek błogosławienia małżeństw i prowadzenie ksiąg zaślubionych. Byli oni mianowani przez prepozyta po konsultacji kapituły konwentualnej. Normalnie zgodnie z konstytucjami kanoników regularnych, kapituły odbywały się każdego roku, a w międzyczasie miały miejsce kongregacje, czyli zebrania członków zarządu prowincji. W zakonach na ziemiach polskich dzielono kaznodziejów najczęściej na dwie grupy: zwyczajnych - ze względu na zakres uprawnień, oraz niedzielnych i świątecznych - z powodu czasu głoszenia kazań $^{10}$.

Konstytucje zakonne sankcjonowały nawet egzamin przed mianowaniem na urząd kaznodziei. Protokoły powizytacyjne kard. Jerzego Radziwiłła z końca XVI wieku żądały, aby po nominacji od prepozyta, kaznodzieja przedstawił się miejscowemu biskupowi diecezjalnemu i otrzymał błogosławieństwo. Posługa kaznodziejska podlegała kontroli, dlatego też spisywał on swoje przemówienia, które miał głosił z pamięci. Obowiązki kaznodziei powierzano kanonikowi regularnemu ze stopniem uniwersyteckim. Dlatego też najczęściej do przepowiadania Słowa Bożego wyznaczano jednego lub dwóch profesorów miejscowego seminarium duchownego. Prawo partykularne zalecało, aby kaznodzieja nie przedłużał kazania ponad godzinę ${ }^{11}$. W klasztorach istniał stały urząd kaznodziei. Głosił on

\footnotetext{
${ }^{8}$ Zielińska, Kultura intelektualna, s. 126-128.

${ }^{9}$ J. Związek, Z dziejów kaznodziejstwa katolickiego w Polsce na przetomie XVI i XVII wieku, „Analecta Cracoviensia”, 23 (1991) s. 229-230.

${ }^{10}$ A.B. Sroka, Prawo i życie polskich reformatów, Kraków 1975, s. 204-205; K. Panuś, Zarys historii kaznodziejstwa w Kościele katolickim, cz. 2, Kraków 2001, s. 32-33; F. Wolański, Kaznodziejstwo bernardyńskie w staropolskim systemie komunikacji społecznej schytku epoki saskiej. Studium ksztattowania wyobraźni i postaw, Torun 2012, s. 30-31.

${ }^{11}$ Constitutiones Canonicorum Regularium Ordinis S. Augustini Congregationis Salvatoris Lateranensis, Romae 1628, s. 36; Wizytacje kanoniczne bp. Jana Konarskiego z 1522 roku i kard. J. Radziwiłła z 1596 roku. K. Łoniewski, Żywot, sprawy y cudowne boskie wstawienie pobożnego kapłana B. Stanisława Kazimierczyka przy Krakowie na Kazimierzu Bożego Ciała kościele, Kraków 1618, s. 7-8, 11. Kard. J. Radziwiłł dostosował się tylko do wytycznych Soboru Trydenckiego okre-
} 
kazania w niedziele i święta. Nie udało się precyzyjnie ustalić, od kiedy w Kraśniku był także dodatkowy kaznodzieja nadzwyczajny, który głosił Słowo Boże $\mathrm{w}$ inne święta. Zgodnie z tradycją zakonną, w największe uroczystości kazania były zastrzeżone dla prepozyta. Podobnie zarezerwowano przepowiadanie opiekunom bractw podczas niedzieli brackich ${ }^{12}$.

Z nekrologów klasztornych i ksiąg miejskich można się dowiedzieć o okresowym istnieniu w konwentach kanoników regularnych osobnych kaznodziejów - polskich i niemieckich, a niektórzy głosili kazania w obu językach. Ponadto, w XVI wieku pojawiło się rozróżnienie na kaznodzieję zwyczajnego i nadzwyczajnego ${ }^{13}$.

Kanonicy regularni w Polsce prowadzili wtedy parafie przy swoich opactwach i prawie wszystkich prepozyturach zakonnych. Osobny kaznodzieja lub kaznodzieje głosili kazania dla członków kongregacji kanonickiej i dla parafian w swoich kościołach. Zakonnicy zasiadali w swoich stallach i pod karą grzywny mieli obowiązek uczestniczyć w nabożeństwie Słowa Bożego. Przed obiadem mogli wysłuchać kazania w języku polskim, a po południu w języku niemieckim. Dotyczyło to także świątyń filialnych (pomocniczych) znajdujących się na terenie parafii kraśnickiej. W Aktach Kapituły Generalnej z 17-22 VIII 1768 roku znajduje się upomnienie dla prepozyta Kraśnika, aby w kaplicy w Stróży regularnie głoszono kazania niedzielne. Ksiądz dojeżdżający i mieszkający tam miał otrzymywać rocznie 100 florenów w dwunastu ratach miesięcznych ${ }^{14}$.

Kongregacja kanoników regularnych zdawała sobie sprawę, że kaznodzieja poprzez dobre i popularne przepowiadanie budował prestiż opactwa, kanonii i prepozytury wśród wiernych, co przyczyniało się wydatnie do wzrostu frekwencji. Ponadto reprezentował on wspólnotę zakonną poza murami klasztornymi. Dlatego też w protokołach Kapituł Generalnych (1647, 1661, 1703 itd.) dość często przypominano kaznodziejom o odpowiedzialnym i starannym przygotowywaniu się do przepowiadania Słowa Bożego ${ }^{15}$. Nic więc dziwnego, że stanowisko kaznodziei umożliwiało drogę awansu do kolejnych, wyższych urzędów w kongregacji. Pełnienie funkcji kaznodziei zapewniało mu powszechny szacunek i uznanie, dlatego też nieraz zabiegano o tę godność. Status kaznodziei cieszył się wysoką

ślonych w Dekrecie o nauczaniu i głoszeniu, rozdział 2, paragraf 13 - ,Zakonnicy z jakiegokolwiek zakonu, nie mogą głosić kazań w kościołach, nawet należących do ich zakonu, jeżeli nie zostali sprawdzeni i uznani przez swoich przełożonych pod względem życia, obyczajów i wiedzy, oraz nie uzyskają ich pozwolenia, z którym - zanim rozpoczną głoszenie kazań - mają obowiązek stawić się osobiście przed biskupem i prosić go o błogosławieństwo". Dokumenty Soborów Powszechnych, oprac. A. Baron, H. Pietras, t. 4, Kraków 2005, s. 249.

${ }^{12}$ Archiwum Klasztoru Bożego Ciała w Krakowie (dalej: ABC), ACG 1700, Considerando venerabile Capitulum vix portabilem quandoque Concionatorum labore $\mathrm{m}$, et quod eosdem alii etiam rogati iurarre nolim decrevit more aliarum Religiorum ut deinceps in unoquoque Conventu Praedicares duo habeatur pro Dominis unus et pro Festi unus exceptis solennionibusque DD. Prepositi et dominicis confraternitatis qua Promotorii Confrarnitatur reservatur, k. 48v .

${ }^{13} \mathrm{~K}$. Latak, Kanonicy regularni laterańscy na Kazimierzu w Krakowie do końca XVI wieku, Ełk 1999, s. 284-295.

${ }_{14}$ ABC, ACG 1767, k. 130v.

${ }^{15} \mathrm{ABC}$, ACG 1703, Contronatores pro omnes Conventus monentur ut se dilipentessime parent ad prae dicationem Dei verbum,. k. 57. 
pozycją w kanonickich kongregacjach zakonnych, a ich funkcja w prawie partykularnym była wymieniana bezpośrednio w rozdziale po prepozycie, przeorze i magistrze nowicjatu ${ }^{16}$. Godność tę powierzano wybitnym kanonikom regularnym, uzdolnionym i cieszących się nienaganną postawą zakonną. Wymagano od kaznodziejów gruntownej znajomości podstaw doktrynalnych, operowania cytatami i dobrej wymowy. Przymioty te były osiągalne dzięki systematycznej lekturze, znajomości Pisma św., teologii i filozofii chrześcijańskiej. Zgodnie z panującymi u kanoników regularnych zwyczajami, kaznodzieje cieszyli się niektórymi przywilejami; zwalniano ich z udziału w części wspólnych modlitw, obowiązków związanych z wykonywaniem różnych prac. Przysługiwało im dodatkowe uposażenie pieniężne ${ }^{17}$. Nie była to jednak funkcja dożywotnia w tym samym klasztorze. Po pewnym czasie kaznodzieję promowano na wyższy urząd albo też przenoszono na równorzędne stanowisko do innego konwentu. Praktyka ta potwierdza poziom i organizację kaznodziejstwa u kanoników regularnych. W połowie XVI wieku Stanisław Niedziela, kaznodzieja z Kazimierza, został „wypożyczony” do opactwa Najświętszej Maryi Panny na Piasku we Wrocławiu. Pod koniec tego wieku w podobnej sytuacji znalazł się ks. Aleksander Wendrzyński, który głosił kazania po polsku i po niemiecku. Na tych samych zasadach przez kilka lat w kanonii kaliskiej urząd kaznodziei pełnił ks. Maciej Miklaszewicz z prepozytury Bożego Ciała. W tym samym charakterze pracował on na Morawach i zmarł w Fulneku. Niestety, nie zachowały się zbiory ich kazań ${ }^{18}$. Podobnie ks. Bartłomiej Mikołaj Cynaki, wywodzący się z włoskich kupców warszawskich, początkowo był związany z kanonickim środowiskiem litewskim. Następnie pod koniec XVIII wieku pełnił obowiązki kaznodziei w Kurozwękach, dwukrotnie w Kraśniku (1700-1703; 1706-1709) $)^{19}$.

Zachowały się niezbyt obszerne informacje na temat kaznodziejstwa kanoników regularnych w XV wieku. Najliczniejsze i najbogatsze źródła z tego okresu dotyczą kongregacji wspólnoty zakonnej i parafii Bożego Ciała na krakowskim Kazimierzu. Jest to związane z miastem stołecznym, będącym centrum intelektualnym, kulturalnym i religijnym Polski. Nie bez znaczenia był fakt, że działał tam wówczas także jako kaznodzieja św. Stanisław Kazimierczyk. W swoim kościele parafialnym głosił on kazania po polsku i po niemiecku ${ }^{20}$.

${ }^{16}$ Constitutiones, s. 36-37. Kaznodziejstwo samodzielne prowadzili dominikanie, franciszkanie, bernardyni, karmelici, augustianie we własnych kościołach zakonnych. Na prowincji aktywnie posłudze głoszenia Słowa Bożego oddawali się głównie dominikanie, franciszkanie, bernardyni i później jezuici.

${ }^{17} \mathrm{~W} 1722$ roku. prepozyt kraśnicki został upomniany na Kapitule Generalnej w Krakowie, że nie wypłacił należnych sum kaznodziei. ABC, ACG 1722.

18 H.D. Wojtyska, Nauka i nauczanie u kanoników regularnych (na przykładzie kongregacji Bożego Ciata), w: Dzieje teologii katolickiej w Polsce, red. M. Rechowicz, t. 2, cz. 2, Lublin 1975, s. 469 .

19 A. Pacevićius, Kanonickie marginalia i proweniencje $w$ zbiorach bibliotecznych Litwy, w: Przemijanie i trwanie. Kanonicy Regularni Laterańscy $w$ dawnej $i$ współczesnej Polsce, red. K. Łatak, I. Makarczyk, Kraków 2008, s. 409.

${ }^{20} \mathrm{~W}$ samym Krakowie i przylegających do niego zespołach miejskich i osadach (Kazimierz, Kleparz, Piasek) w XV wieku funkcjonowało 12 parafii. W kościołach parafialnych i zakonnych 
Na rozgłos klasztoru wpływały takie czynniki jak: przestrzeganie przez zakonników obserwancji zakonnej, prowadzenie szkoły na wysokim poziomie, odpowiednie zaopatrzenie biblioteki, wzorcowa praca duszpasterska i udzielanie się na zewnątrz kaznodziejów. W miejskich kościołach parafialnych w Polsce instytucja stałych kaznodziejów była zjawiskiem normalnym. Ponadto przepisy synodalne zalecały, aby wierni każdej narodowości mieli możliwość słuchać kazań $\mathrm{w}$ zrozumiałym dla siebie języku ${ }^{21}$.

Pośrednio, do podniesienia poziomu kaznodziejstwa w Kościele katolickim przyczyniła się reformacja. Kazanie stało się wtedy centrum liturgii. Dlatego też w celu odpowiedzi na zapotrzebowania społeczeństwa, jak i „osłabienia przeciwnika", bardziej zadbano o drukowanie materiałów pomocniczych dla kaznodziejów, jak i ich odpowiednie przygotowanie. W renesansie bardziej rozpowszechniły się kazania typu homiletycznego, polemicznego i apologetycznego. Doniosłe znaczenie problematyki związanej z kaznodziejstwem opracowano i ogłoszono na trzech sesjach Soboru Trydenckiego: w Dekrecie o nauczaniu i głoszeniu - V 17 III 1548 roku, XXII 17 IX 1562 roku - rozdział 8, Nauka i kanony o Najświętszej ofierze mszy świętej, XXIV 11 XI 1563 roku - kanon 4, Dekret o reformie ${ }^{22}$. Jednocześnie, podczas trwania tego soboru, zagadnieniami związanymi z kaznodziejstwem zajmowały się polskie synody prowincjonalne (plenarne), zwoływane i odprawiane pod przewodnictwem prymasów. 17 maja 1557 roku na synodzie w Piotrkowie zalecono głosić Słowo Boże ,z należytą powagą i nieskażone, zgodnie z nauką Ojców Kościoła i ustawami synodalnymi, bez żartów, bajek i innych ludzkich opowiadań". Prymas Polski, arcybiskup gnieźnieński, Mikołaj Dzierzgowski, został zobowiązany do wydania homiliarza i katechizmu dla wiernych ${ }^{23}$. Podobnie, na synodzie prowincjonalnym w Warszawie z 1561 roku, odbytym pod prezydencją prymasa Jana Przerębskiego, powrócono do zagadnienia związanego $z$ drukowaniem pomocy homiletycznych dla księży ${ }^{24}$. Uchwały wyżej wymienionych polskich synodów plenarnych ściśle wiązały się z zaleceniami Soboru Trydenckiego, a nawet go wyprzedzały.

Do pierwszych znanych $\mathrm{z}$ imienia i nazwiska kaznodziejów prepozytury kraśnickiej należy zmarły między 1507 a 1512 rokiem. Jan z Lublina. Był on magistrem atrium i jest prawdopodobne, że w kraśnickim konwencie powierzono mu obowiązki przepowiadania Słowa Bożego. Z XVI wieku znamy jeszcze trzech kanoników regularnych zajmujących się posługą głoszenia Słowa Bożego, a są to: Jan Myslovius, Jan Turobinius i Marcin Nowoyski z Mielca. Największe osiągnięcia w kaznodziejstwie odnotowali kanonicy regularni w pierwszej połowie XVII wieku. Spośród nich z pewnością wyróżniał się ks. Jan Augustyn Biesiekierski herbu Pomian, którego owocna działalność pisarska i kaznodziejska

wierni mieli do wyboru 18 kazań polskich i 6 niemieckich. Vita sancti doctoris Joannis Canti, w: Monumenta Poloniae Historica, t. VI, Warszawa 1961, s. 511.

${ }^{21}$ Wolny, Kaznodziejstwo, s. 304.

${ }^{22}$ Dokumenty Soborów Powszechnych, t. 4, s. 241-249, 645, 743.

${ }^{23}$ Subera, Synody prowincjonalne, s. 133-134; J. Związek, Katolickie poglądy polityczno-spoteczne w Polsce na przełomie XVI i XVII wieku w świetle kazań, Lublin 1977, s. 26-28.

${ }^{24}$ A. Jougan, Homilie polskie od czasów najdawniejszych aż po dobę obecna, Lwów 1902, s. 60-61. 
wykraczała poza mury własnego klasztoru i kościoła. Urodził się w 1567 roku prawdopodobnie w Besiekierach w województwie łęczyckim ${ }^{25}$. W 1587 roku J. A. Biesiekierski wstąpił do jezuitów w Wilnie, następnie studia seminaryjne odbył w Poznaniu i ok. 1600 roku przyjął święcenia kapłańskie. Był wykładowcą retoryki w kolegiach jezuickich w Lublinie i Jarosławiu, oraz teologii polemicznej w Kaliszu i prefektem szkół w Sandomierzu, rektorem kolegium w Jarosławiu. Od 1607 roku pełnił obowiązki kaznodziei w Poznaniu i tam w 1615 roku wydrukował kazanie wygłoszone na św. Andrzeja w kościele św. Marii Magdaleny - Kościót nowotny prawdziwym Kościołem być nie może. Pod koniec pobytu u jezuitów w latach 1616-1619 był superiorem rezydencji w Przemyślu ${ }^{26}$.

W roku $1621 \mathrm{~J}$. A. Biesiekierski opuścił zakon jezuitów i przeszedł do kanoników regularnych laterańskich Bożego Ciała w Kazimierzu pod Krakowem. Wkrótce powierzono mu wykłady $\mathrm{z}$ teologii w studium klasztornym. Z pewnością należał on do wybitnych pionierów, który swoje nieliczne, ale różnorodne prace o charakterze historycznym, polemicznym i kaznodziejskim ogłosił drukiem. W publikacji Krótka nauka o czci i poszanowaniu obrazów świętych (Kraków 1624) przedstawił syntetycznie dzieje kanoników regularnych i cudownego obrazu NMP w kościele Bożego Ciała. Niestety, zaginął rękopis przygotowanego do druku tekstu Żywoty Stanisława Kazimierczyka. Najobszerniejszą publikacją zwarta jest kazanie wygłoszone w kościele farnym w Kraśniku na pogrzebie Wojciecha z Wybranowa - Szlachcic polski starożytny, na pogrzebie sławnej pamięci J. M. Pana Wojciecha Wybranowskiego, wystawiona w kościele Kraśnickim farnym od X. Jana Augustyna Biesiekierskiego (Lublin 1632, ss. 40). Wymienione opracowania, dobrze udokumentowane argumentami historyczno-teologicznymi, były też odpowiedzią protestantom na ich zarzuty skierowane przeciwko Kościołowi katolickiemu. Ten wyróżniający się kanonik regularny zmarł w 1635 roku w Kraśniku i tam został pochowany ${ }^{27}$.

Poza wspomnianym powyżej ks. Biesiekierskim, jeszcze dwóch kanoników regularnych pracujących w Kraśniku pozostawiło po sobie zbiory drukowanych kazań: ks. Jakub Fulgencjusz Hasjusz (1653) i ks. Adam Benedykt Samotulski, wcześniej w latach 1658-1685 długoletni prepozyt wileński i budowniczy kościo-

${ }^{25}$ Bracia Jan i Mikołaj Sokołowscy herbu Pomian w 1531 roku nabyli Besiekiery wraz z rycerskim zamkiem i od niego nazwali się Biesiekierskimi. Potomkowie Jana przenieśli się na Litwę i nie wiadomo, z jakich powodów kilku z nich przyjęli herb Topór. Być może z tych powodów ks. Ludwik Grzebień w Stowniku Polskich Teologów Katolickich (dalej: SPTK), t. 1, s. 147, podał Wielkopolskę jako miejsce urodzenia J.A. Biesiekierskiego, a powiat grodzieński w Encyklopedii wiedzy o jezuitach na ziemiach Polski i Litwy 1564-1995, Kraków 1996, s. 47; H. Stupnicki, Herbarz Polski, t. 1, Lwów 1855, s. 34; Besiekiery, w: Słownik Geograficzny Królestwa Polskiego i innych krajów słowiańskich, t. 1, red. F. Sulimierski, B. Chlebowski, W. Walewski, Warszawa 1880, s. 156157; S. Uruski, Rodzina herbarz szlachty polskiej, t. 1, Warszawa 1904, s. 209-210.

${ }^{26}$ Biesiekierski Jan (Augustyn), w: Encyklopedia wiedzy o jezuitach na ziemiach Polski i Litwy 1564-1995, oprac. L. Grzebień, Kraków 1996, s. 47.

${ }^{27} \mathrm{ABC}$, Memoriale Fratrum et Benefactorum defunctorum Congregationis Canonicorum Regularium Laterainsium, k. 37; L. Grzebień, J. Mandziuk, Biesiekierski Jan Augustyn, SPTK, t. 1, s. 147. 
ła św. Piotra i Pawła na Antokolu. Pod koniec życia pełnił obowiązki przełożonego w Kraśniku, gdzie zmarł 2 marca 1686 roku $^{28}$.

Do tego grona pierwszych wybitnych kanoników regularnych, którzy pisali dzieła teologiczne i publikowali je drukiem należał także ks. Paweł Pukal, zmarły w 1631 roku. Był on znanym kaznodzieją w Krakowie i Kraśniku oraz prepozytem w Bychowie (1622-1628). Urodził się 18 czerwca 1584 roku w Kazimierzu k. Krakowa, w rodzinie patrycjuszowskiej, jako syn Andrzeja i Reginy. W 1600 roku rozpoczął studia na Wydziale Artium Uniwersytetu Krakowskiego, a w 1605 roku wstąpił do kanoników regularnych. W latach 1609-1612 kontynuował edukację w Padwie i tam uzyskał stopień doktora teologii oraz przyjął święcenia kapłańskie. Następnie wrócił do Polski i jako kolekcjoner posiadał znaczący zbiór ksiąg prywatnych. W 1617 roku wydał rozmyślania pasyjne tłumaczone z języka włoskiego, a w 1619 roku opublikował drukiem Genealogię Jana de Nigra Valle, która była w Polsce pierwszym źródłem do poznania historii kanoników regularnych laterańskich. Od 1628 roku rezydował w Krakowie, gdzie był lektorem studium klasztornego, kaznodzieją zwyczajnym i promotorem Bractwa Najświętszego Sakramentu i Pięciu Ran Pana Jezusa ${ }^{29}$.

Litwin z pochodzenia, ks. Jan Chryzostom Korsak, był pierwszym prepozytem w Krzemienicy w powiecie wołkowyskim (1617-1631). Jemu przypadł zaszczyt w 1621 roku wygłoszenia kazania na pogrzebie fundatora Mikołaja Wolskiego, dziedzica tej miejscowości i kasztelana witebskiego. Egzorta ta odznaczająca się pięknym stylem została w całości opublikowana drukiem. Wypada nadmienić, że ks. Korsak pełnił dodatkowo obowiązki wizytatora klasztorów w Wielkim Księstwie Litewskim (1628-1641) i był prepozytem w Kraśniku (1641-1644). Pod koniec życia przebywał w Kazimierzu w charakterze przeora i tam zmarł 3 lipca 1652 roku podczas epidemii dżumy ${ }^{30}$.

W I Rzeczypospolitej okres odrodzenia kończy się umownie potopem szwedzkim. Kazania barokowe były obrazem psychiki i obyczajowości społeczeństwa tej epoki. Kaznodzieje poruszali problemy codzienności, a ich zbiory można pośrednio zaliczyć do pewnego rodzaju kronik wydarzeń historycznych. Wystąpienia kaznodziejów były zasadniczo $\mathrm{w}$ tonie pogodnym, a nawet żartobliwym i dow-

${ }^{28}$ ABC, ACG, k. 57v.; Memoriale Fratrum, k. 61; K. Łatak, Ksiadz Stefan Ranatowicz CRL (1617-1694). Barokowy kronikarz i pisarz klasztorny, Kraków 2010, s. 83, 94, 101.

${ }^{29}$ Katalog prepozytów sporządzony na podstawie akt kapituł generalnych, wizytacji i nekrologu zakonnego przechowywany w Archiwum Klasztoru Bożego Ciała w Krakowie. P. Pukal, Gemealogia Sacri et Apostolici Ordinis Canonicorum Regularium S. Augustini ex Congregatione Lateranensi S. Salvatoris contexta olim a Joanne de Nigra Valle Ordinis Premonstratensium, Kraków 1619; W. Urban, Losy wychowanków Akademii Krakowskiej w drugiej połowie XVI i pierwszej połowie XVII wieku, w: Studia z dziejów młodzieży Uniwersytetu Krakowskiego w dobie renesansu, Kraków 1964, s. 184-185; K. Targosz, Biogramowy wykaz osób występujacych w metryce, w: Archiwum nacji polskiej w Uniwersytecie Padewskim, t. 1, Wrocław 1971, s. 362-363; E. Ozorowski, Pukal Pawet, SPTK, t. 3, s. 460-461; Łatak, Ksiadz Stefan Ranatowicz CRL (1617-1694), s.79-80.

${ }^{30} \mathrm{ABC}$, Memoriale Fratrum, k. 81; A. Błachut, W pięćsetna rocznicę zatożenia klasztoru Bożego Ciała na Kazimierzu w Krakowie (1405-1905). Szkice dziejów opactwa Kanoników Regularnych Laretańskich, Kraków 1905, s. 59; K. Łatak, Kongregacja krakowska kanoników regularnych laterańskich na przestrzeni dziejów, Kraków 2002, s. 116-118; Pacevićius, Kanonickie marginalia, s. 406-407. 
cipnym, okraszone masą szczegółów drugoplanowych. Duże znaczenie na rozwój kaznodziejstwa miał rozkwit misji ludowych i ożywienie kultu maryjnego (sanktuaria maryjne, koronacje cudownych obrazów, pielgrzymki) ${ }^{31}$.

Szczególnym wyrazem uznania dla kaznodziei zakonnego tego okresu było skierowanie go do pracy w katedrze i publikacja drukiem jego zbiorów. Do grona popularnych i cenionych kaznodziejów tego okresu na trwałe wpisał się prepozyt Bożego Ciała, ks. Jacek Liberiusz. Urodził się w 1599 roku w Kazimierzu k. Krakowa, jako syn Jana Wolnego rajcy miejskiego i Zofii. Edukację rozpoczął w domu rodzinnym i szkole parafialnej kanoników regularnych. Do tego konwentu został przyjęty w 1617 roku i po rocznym pobycie złożył śluby zakonne. W 1618 roku podjął studia w Uniwersytecie Krakowskim, które w 1622 roku uwieńczył stopniem mistrza sztuk wyzwolonych (magistra). Przez dwa lata prowadził zajęcia dydaktyczne na tejże uczelni i prawdopodobnie w 1624 roku otrzymał święcenia kapłańskie. W latach 1626-1628 uczył się w Cremonie w zakonnym studium teologii włoskich kanoników regularnych laterańskich i w Rzymie uzyskał doktorat z teologii ${ }^{32}$. Do Krakowa wrócił w 1630 roku i w styczniu następnego roku na kapitule konwentualnej powierzono mu obowiązki kaznodziei, lektora filozofii w studium klasztornym, spowiednika księży, a później też mistrza nowicjatu. Urzędy te pełnił do 1638 roku Na wniosek opata komendatoryjnego Czerwińska, królewicza Karola Ferdynanda Wazy, został wypożyczony do tej wspólnoty zakonnej, aby podnieść poziom naukowy kanoników tego ważnego ośrodka na Mazowszu. Przez prawie trzy lata łączył tam obowiązki nauczyciela filozofii i teologii z funkcją kaznodziei. W 1640 roku został wybrany koadiutorem prepozyta ks. Marcina Kłoczyńskiego i po jego śmierci w 1644 roku rozpoczął samodzielne urzędowanie w klasztorze i parafii. Pozostało po nim ok. $100 \mathrm{opu}-$ blikowanych drukiem kazań głównie mariologicznych i chrystologicznych, które stanowią cenny przyczynek do dziejów kultury staropolskiej XVII wieku. Jego liczne kazania maryjne, oryginalne co do formy i treści, są ciągle przedmiotem zainteresowań mariologów. Wśród najbardziej znanych zbiorów wydrukowanych kazań należy wymienić: Gospodyni Nieba i Ziemi (1657), Gospodarz Nieba i Ziemi Jezus Chrystus (1665, 1667), Gwiazda Morzka Najświętsza Maryja Panna (1670) i inne. Co do treści, nie są one wolne od panującej wówczas „mody barokowej", ale zdecydowanie przeważają w nich pozytywne zalety. Ks. J. Liberiusz zmarł 23 października 1673 roku w klasztorze i został pochowany w grobowcu prepozyckim w prezbiterium kościoła Bożego Ciała na Kazimierzu ${ }^{33}$.

Szczególną sławą niezwykłego kaznodziei cieszył się ks. Ludwik Szymon Faściszewski (1608-1667). Należał on do grona najwybitniejszych kanoników

${ }^{31}$ Duże zasługi w dziedzinie prowadzenia misji ludowych położyli jezuici, franciszkanie, misjonarze św. Wincentego a Paulo, a następnie redemptoryści. Do głównych zadań kazań eschatologicznych należało doprowadzenie słuchaczy do skruchy i nawrócenia. K. Górski, Studia i materiały $z$ dziejów duchowości, Warszawa 1980, s. 262-264; G. Siwek, Misje ludowe w teorii i praktyce Kościoła, Kraków 1999, s. 52, 57-58; Panuś, Historia kaznodziejstwa, s. 257-258.

${ }^{32}$ E. Ozorowski, Liberiusz (Liberius) Jacek, SPTK, t. 2, s. 524-525; K. Łatak, Poczet rządców opactwa Bożego Ciała Kanoników Regularnych Laterańskich w Krakowie, Kraków 2005, s. 98-99.

${ }_{33}$ Wojtyska, Nauka i nauczanie u kanoników regularnych, s. 466-467; J. Bieniarzówna, Liberiusz Jacek, PSB, t. 17, Wrocław 1972, s. 282-283. 
regularnych pracujących w Kraśniku. Po studiach specjalistycznych we Włoszech i uzyskaniu tam stopnia doktora teologii w 1650 roku w Rzymie (Sapienza) powrócił do Polski i pełnił obowiązki zwyczajnego kaznodziei w Kazimierzu i Kraśniku. W 1651 roku przeprowadził wizytację klasztorów kanoników regularnych w Wielkim Księstwie Litewskim i dzięki temu pozytywnie zaprezentował się zarządowi diecezji wileńskiej. Ks. L. Faściszewski przygotował do druku zbiór swoich kazań, jednak nie zdążył ich opublikować. Zmarł 26 maja 1667 roku w Kraśniku i tam został pochowany. Obszerny rękopis kazań zaginął, być może dlatego, że z dorobku tego wybitnego kaznodziei zbyt często korzystali inni kanonicy ${ }^{34}$.

W przeciwieństwie do jezuitów, dominikanów czy bernardynów, przedstawiciele kanoników regularnych rzadko dostąpili na stałe zaszczytnego urzędu kaznodziei katedralnego. Wypada zaznaczyć, że kongregacja krakowska posiadała tylko dwie prepozytury w stolicach diecezji, tj. w Krakowie i Wilnie. Mimo dość dużej konkurencji w drugiej połowie XVII wieku ks. Jacek Liberiusz był zapraszany z okolicznościowymi kazaniami do katedry wawelskiej i do znaczniejszych kościołów Krakowa: mariackiego, karmelitów na Piasku, bernardynów na Stradomiu, dominikanów i franciszkanów. Podobnie w następnym wieku ks. Karol Wysuszył został zauważony i doceniony przez centralne władze diecezji krakowskiej, które powierzyły mu głoszenie kazań jubileuszowych w kościele mariackim i stołecznej katedrze. Kilku kanoników regularnych potwierdziło swój kunszt kaznodziejski na terenie Wilna, np. ks. Joachim Wyszyński był zapraszany przez jezuitów do głoszenia Słowa Bożego w kościele akademickim. W stołecznej katedrze głosił kazania ks. Augustyn Adam Małachowski, prepozyt w Słonimiu (1688-1691) i biskup nominat na sufraganię smoleńską. Jego dwa kazania ukazały się drukiem. Podobnie też głosił tam kazania, także w języku litewskim, ks. Bruno Kontrym ${ }^{35}$.

W okresie oświecenia w I Rzeczypospolitej kazania wygłaszano w sposób podniosły, a jednym z ich celów było spowodowanie w słuchaczach przekonania do przyjęcia jakiejś prawdy lub uwrażliwienia na wolę poprawy postępowania. Ponadto, dość sztywno przestrzegano jedności tematu. Co więcej, kaznodzieje oprócz tematów ściśle religijnych i umoralniających, w tym piętnowania wad narodowych epoki saskiej takich, jak: pycha, obłuda, pijaństwo, pochlebstwo, płaszczenie się, podejmowali także problemy zagrażające integralności państwa, a w tym liberum veto i ucisk chłopa. Niestety, przepowiadanie kościelne wieku oświecenia było w większości pozbawione charakteru nadprzyrodzonego, co w konsekwencji doprowadziło do kryzysu kaznodziejstwa ${ }^{36}$.

\footnotetext{
${ }^{34}$ Archiwum Klasztoru OO. Paulinów na Jasnej Górze, sygn. 254, Acta visitationum seu prepositorum Canonicorum Regularium Lateranensium; M. A. Gorczyński, Schema de Canonicis Regularibus Lateranensibus Congregationis Cracoviensis, w: Joannes de Nigro Valle, Genealogia Sacri et Apostolici Ordinis Canonicorum Regularium, Kraków 1707, s. 118.

${ }^{35}$ Bieniarzówna, Liberiusz Jacek, s. 282; Pazera, Kaznodziejstwo w Polsce, s. 265-269; I. Makarczyk, Procesy informacyjne biskupów polskich z zakonu kanoników regularnych laretańskich, w: Przemijanie i trwanie, s. 236.

${ }^{36}$ W. Rubin, Lud w polskim ustawodawstwie synodalnym do rozbiorów Polski, Rzym 1955, s. 26-32; W. Szetelnicki, Kaznodziejstwo polskie XVI i XVII wieku w obronie ludu, „Nasza Prze-
} 
Podczas niewoli narodowej katolicyzm polski zespalał się z religijnie motywowanym patriotyzmem. Do takiego stanu przyczynili się sami zaborcy, którzy uciskali zarówno polskość, jak i wyznawców Kościoła rzymskokatolickiego. Propagowany stereotyp Polak-katolik odgrywał rolę obronną w stosunku do atakowanych przez zaborców takich wartości jak tożsamość narodowa, tradycja historyczna i idea niepodległościowa. Dlatego też Polacy w walce o wolność stawiali na tym samym poziomie powinność religijną i patriotyczną. Kazania w tym duchu głosili głównie księża związani z posługą kapelanów wojskowych, ruchem konspiracyjnym, obchodami sławnych rocznic czy sprowadzaniem prochów wieszczów i bohaterów narodowych ${ }^{37}$.

W pewnym stopniu w nurt ten wpisuje się owocna działalność prepozyta klasztoru Bożego Ciała, ks. Tomasza Franciszka Madejskiego. Urodził się 29 września 1799 roku w Bieżanowie koło Krakowa. Wykształcenie średnie zdobył w Krakowie i w 1816 roku wstąpił do kanoników regularnych. Śluby zakonne złożył 27 stycznia 1818 roku w Kościele Bożego Ciała na Kazimierzu. Następnie w Kraśniku odbył studia seminaryjne i 19 stycznia 1823 roku otrzymał święcenia kapłańskie w Lublinie. W latach 1823-1829 pracował w Kraśniku jako zakrystianin, promotor bractw i kaznodzieja. Zachowane w krakowskim klasztorze rękopisy kazań ks. Madejskiego pozwalają wyciągnąć wnioski o jego dobrym przygotowaniu teologicznym, znajomości literatury, historii Kościoła i dziejów ojczystych. Od marca 1829 roku przebywał w Krakowie, gdzie pełnił obowiązki kaznodziei, zakrystianina i przez pięć miesięcy magistra nowicjatu. W 1831 roku wrócił do Kraśnika i na nowo podjął poprzednie urzędy. Ponadto, był też magistrem nowicjatu ${ }^{38}$. Podczas obrad kapituły generalnej w Krakowie w 1836 roku ks. Madejski został wybrany przeorem krakowskim. Wśród aktywnie prowadzonych prac, otoczył też opieką bibliotekę klasztorną. Prepozyt interesował się sprawami społecznymi i narodowymi. Wyrazem tego było poparcie powstania listopadowego, a następnie udział w manifestacji 1846 roku na Podgórzu, zorganizowanej przez Edwarda Dembowskiego. Za taką postawę władze austriackie wtrąciły go do więzienia w Krakowie, a 12 maja 1849 roku ponownie aresztowały i skazały na roczny pobyt $\mathrm{w}$ twierdzy ołomunieckiej, skąd 20 lutego 1850 roku wyszedł na wolnośćc ${ }^{39}$. Pod naciskiem władz cywilnych musiał opuścić klasztor i za zgodą konsystorza krakowskiego zamieszkał w domu emerytów i pomagał w pracy duszpasterskiej w parafii Wszystkich Świętych w Krakowie. Mimo eksklaustracji, utrzymywał kontakty z kanonikami regularnymi, a w latach 1854-1858 ponownie przebywał we wspólnocie zakonnej. Życie zakończył poza klasztorem jako wikariusz parafii Wszystkich Świętych i penitencjariusz w kościele mariackim. Zmarł

szłość", 37 (1972) s. 49; J. Śrutwa, Oświecenie w Polsce i jego wptyw na życie kościelne, w: Historia Kościoła w Polsce, t. 2, cz. 1, red. B. Kumor, Z. Obertyński, Warszawa-Poznań 1979, s. 34-37; Panuś, Zarys historii kaznodziejstwa w Kościele katolickim, cz. 2, s. 289-295.

${ }^{37}$ M. Brzozowski, Kaznodziejstwo i sprawa narodu. Elementy teologii wyzwolenia $w$ kaznodziejstwie polskim XIX wieku, „Znak”, 398 (1988) s. 38-49; Z. Zieliński, Kościót i naród w niewoli, Lublin 1995, s. 23-29.

${ }^{38}$ Schematismus Dioecesis Lublinensis 1824-1829; Łatak, Kongregacja krakowska, s. 332-336.

${ }^{39}$ Latak, Poczet rzadców, s. 175-178. 
7 lutego 1876 roku w Krakowie i został pochowany na Cmentarzu Rakowickim. W Archiwum Bożego Ciała pozostały po nim dwa pokaźne zbiory kazań ${ }^{40}$.

Na polu oświaty, jako propagator nowoczesnego szkolnictwa, zasłużył się ks. Antoni Firman Lubaczewski, prepozyt kraśnicki (1820-1853), a od 1836 roku także prepozyt generalny kongregacji krakowskiej. Chociaż nie posiadał on oficjalnej nominacji na urząd kaznodziei, to jako proboszcz kraśnickiej parafii odznaczał się darem słowa i dał się poznać jako wytrawny mówca nie tylko w klasztornej świątyni, ale i na zewnątrz, poza wspólnotą zakonną. Urodził się 16 czerwca 1791 roku we wsi Wojcieszków w ziemi łukowskiej z rodziców Józefa i Antoniny, zubożałej szlachty. Z niepełnym wykształceniem średnim, zdobytym w Zamościu, w 1810 roku zgłosił się i został przyjęty do kanoników regularnych w Kraśniku. Następnie został wysłany do nowicjatu w Krakowie i tam 31 października 1813 roku złożył uroczystą profesję zakonną. W tamtejszym klasztorze odbył studia filozoficzno-teologiczne, a w styczniu 1815 roku w Lublinie przyjął święcenia kapłańskie i wrócił do konwentu kraśnickiego ${ }^{41}$. Po otwarciu nowicjatu i seminarium w Kraśniku ks. Lubaczewski prowadził wykłady z filozofii i teologii oraz otrzymał nominację na socjusza magistra nowicjatu. W maju został mianowany administratorem prepozytury kraśnickiej, a po roku prepozytem. Jako prepozyt generalny kongregacji krakowskiej nadal mieszkał w Kraśniku i zatrzymał dotychczasowy urząd lokalnego prepozyta. Pod koniec życia ciężko chorował i wyjeżdżał na kuracje. Zmarł w Kraśniku 25 kwietnia 1853 roku na skutek wylewu i został pochowany w zakonnym kościele ${ }^{42}$.

Podobnie w sprawy narodowo-patriotyczne był zaangażowany opat krakowski, ks. Stanisław Dominik Słotwiński. Urodził się 23 września 1828 roku w Bełżycach na Lubelszczyźnie w rodzinie zubożałej szlachty Tomasza i Marianny z Ostrowskich. Jego ojciec był cenionym w mieście mistrzem szewskim. Stanisław Dominik po ukończeniu szkoły elementarnej kształcił się w gimnazjum w Lublinie, które słynęło z wysokiego poziomu nauczania. Jako zdolny i pilny uczeń, w 1846 roku wstąpił do kanoników regularnych laterańskich w Kraśniku, gdzie po rocznej formacji podstawowej złożył profesję zakonną, a w 1848 roku otrzymał święcenia niższe w Sandomierzu. Jako młody, energiczny kleryk zajmował się tajnym nauczaniem zwłaszcza dzieci wiejskich. By uniknąć represji za działalność oświatową i patriotyczną, Słotwiński wyjechał do Krakowa. Chociaż przebywał tam nielegalnie, to jednak podjął edukację w seminarium duchownym. Ponieważ nie posiadał wymaganego obywatelstwa galicyjskiego, udał się do Paryża. Tam w centrum polskiej emigracji kontynuował naukę. Przy okazji odwiedził Hotel Lambert i spotkał się z czołowymi przedstawicielami kultury polskiej: Adamem Mickiewiczem, Cyprianem Kamilem Norwidem i ks. Piotrem Semenenko. Od jesieni 1849 roku przebywał w klasztorze kanoników regularnych w Rzymie i tam w 1851 roku przyjął święcenia kapłańskie. W kolegium zakonnym przy kościele św. Piotra w Okowach powierzono mu obowiązki profesora i magistra

${ }^{40}$ ADC, Cathalogus Fratrum defunctorum, s. 17; Elenchus Venerabilis Cleri Dioecesis Ceacoviensis 1872, s. 21.

${ }^{41}$ ABC, Dalszy Poczet Prałatów, s. 23; Tekst kazania wygłoszonego na pogrzebie; Liber capitulorum localium, s. 97, 102-103.

${ }^{42}$ ABC, Cathalogus Fratrum definitorium, s. 58; Łatak, Poczet rządców, s. 157-166. 
kleryków. Szybko zdobył popularność w Wiecznym Mieście z powodu pięknych i głębokich kazań, recytacji wierszy i doskonałej gry na skrzypcach ${ }^{43}$. Na pisemne prośby kanoników regularnych z Krakowa, w 1856 roku wrócił do klasztoru Bożego Ciała i wkrótce na kapitule konwentualnej jednogłośnie został wybrany przełożonym tej wspólnoty zakonnej. Kapituła generalna obradująca w 1861 roku w Rzymie podniosła klasztor Bożego Ciała do rangi opactwa, a 33-letniego ks. Słotwińskiego mianowała pierwszym opatem. Energiczny, rygorystyczny i kontrowersyjny przełożony, głównie poprzez pracę z bractwami, nowe formy kaznodziejstwa i organizowanie podniosłych uroczystości odpustowych, starał się ożywić parafię miejską. Przez to pozyskał sympatię mieszkańców Krakowa, uznanie władz świeckich i najwyższych władz kościelnych ${ }^{44}$.

Ksiądz Słotwiński, jako przedsiębiorczy i aktywny przełożony, mimo iż na stałe był związany z opactwem Bożego Ciała, utrzymywał żywe kontakty z innymi klasztorami kongregacji krakowskiej: w Wilnie, Kraśniku i Wolbromiu. Włączył się też w życie diecezji krakowskiej i 10 grudnia 1862 roku witał mową pochwalną w kościele Piotra i Pawła administratora apostolskiego diecezji krakowskiej biskupa Antoniego Gałeckiego. Ponadto, koronował obraz Matki Bożej u dominikanów w Borku k. Rzeszowa, uczestniczył w koronacji wizerunków maryjnych u karmelitów w Krakowie, bernardynów w Kalwarii Zebrzydowskiej i u jezuitów w Starej Wsi. Pojechał na Międzynarodowy Kongres Mariologiczny we Fryburgu (1902), a w 1904 roku na pierwszym Polskim Kongresie Mariologicznym we Lwowie wygłosił krótki referat na temat Stanisława Kazimierczyka ${ }^{45}$.

Opat Słotwiński nie angażował się aktywnie w wielką politykę i był przeciwnikiem zbrojnego wyzwolenia Polski, chociaż z entuzjazmem pisał do opata generalnego w Rzymie o powstaniu styczniowym. Uzyskanie niepodległości czy szerzenie polskości widział w katolicyzmie, w udziale w obrzędach religijnych, posłudze duszpasterskiej, prowadzeniu wydawnictw i ośrodków wychowawczych. $Z$ jego pozytywistycznej postawy wynika, że los Ojczyzny nie był mu obojętny. Jako kaznodzieja wybitnie patriotyczny dał się poznać szczególnie w 1890 roku, kiedy został poproszony o wygłoszenie kazania w katedrze wawelskiej z okazji sprowadzenia prochów Adama Mickiewicza. Podobnie też w 1898 roku na Rynku Krakowskim, pięknym okolicznościowym przemówieniem uczcił stuletnią rocznicę urodzin wieszcza. Budujące i patriotyczne kazanie wygłosił w Krakowie w 1895 roku, wykorzystując smutną, setną rocznicę utraty państwowości polskiej ${ }^{46}$.

Ksiądz Słotwiński, jako ceniony i bardzo popularny kaznodzieja, nie oddawał się pasji pisarskiej. Być może, to stało się powodem, że tylko kilka kazań i mów okolicznościowych oraz pogrzebowych ukazało się drukiem pod koniec jego życia. Były to przeważnie przemówienia z okazji świąt kościelnych (kazanie na uro-

${ }^{43}$ Ks. Opat Stanisław Dominik Stotwiński, http://www.szkolakamien.czerchichow.pl/pliki/ ks.Slotwinski.pdf, (dostęp: 17.09.2014).

${ }^{44}$ Latak, Poczet rzadców, s. 193-199.

${ }^{45}$ Tamże, s. 201-204.

${ }^{46} \mathrm{~W}$. Martuszewski, Archiwalia dotyczące polskich kanoników regularnych laterańskich $w$ Archiwum Generalnym Zakonu w Rzymie, w: Przemijanie i trwanie, s. 350-355. 
czystość narodzenia NMP, Kraków 1901), uroczystości szkolnych (przemówienie podczas zakończenia roku szkolnego w szkole miejskiej w Podgórzu, Kraków 1902) i odezwa do pobożnych Polek (Kraków 1903).

W roku 1893 ks. Słotwiński zrezygnował z pełnienia obowiązków opata i wkrótce zamieszkał u sióstr szarytek w Moszczanach k. Radymna w charakterze kapelana szpitala i sierocińca. Tam zmarł 17 lutego 1905 roku na skutek zapalenia płuc i został pochowany na miejscowym cmentarzu ${ }^{47}$.

Przez rok 1802/1803 urzędowym kaznodzieją w kraśnickim konwencie był ks. Wincenty Floryd Mydlarski. Urodził się 26 marca 1779 roku z zamożnych rodziców Jana i Katarzyny z Jastrzębskich na Kazimierzu w Krakowie. W 1793 roku wstąpił do kanoników regularnych w miejscowym klasztorze, a w 1796 roku przeniesiono go do Kraśnika. Na nowym miejscu studiował filozofię, a na studia teologiczne został wysłany do dominikanów w Lublinie. 4 lipca 1802 roku przyjął święcenia kapłańskie w Kunowie i wrócił do Kraśnika. Następnie został skierowany do Krakowa i 29 czerwca 1814 roku na kapitule generalnej wybrano ks. Mydlarskiego prezpozytem generalnym. Urząd ten pełnił do śmierci w 1836 roku i jako pierwszy z prepozytów został pochowany nie w kościele Bożego Ciała, ale na Cmentarzu Rakowickim ${ }^{48}$.

W ramach represji po upadku powstania styczniowego klasztor kanoników regularnych w Kraśniku został skasowany przez carat. Za czynne poparcie zrywu narodowego, wygłaszanie kazań patriotycznych i przechowywanie powstańców skazano i wywieziono do klasztoru paulinów na Jasnej Górze trzech księży: Szymona Królikowskiego, Ludwika Żytko i ostatniego prepozyta - Andrzeja Sobańskiego ${ }^{49}$.

Większość kaznodziejów kanoników regularnych łączyła kaznodziejstwo ze sprawowaniem funkcji administracyjnej w kongregacji. Ta aktywność ułatwiała im publikowanie własnych kazań. Od XVI wieku kazania już nie tylko wygłaszano, ale zaczęto również publikować w języku polskim. Dorobek piśmienniczy kaznodziejów wywodzących się z kanoników regularnych laterańskich czeka jeszcze na szczegółowe badania i opracowanie. Trudno jest precyzyjnie określić, ile kazań wydali samodzielnie i w jakich językach ${ }^{50}$.

Osobną kategorię stanowi rękopiśmienny dorobek kaznodziejów z kongregacji kanoników regularnych św. Augustyna. Jego systematyzację utrudnia skomplikowana historia związana z kasatami klasztorów, przenoszeniem i rozproszeniem archiwaliów. Poza nielicznymi zbiorami kazań przechowywanych

${ }^{47}$ Latak, Kongregacja krakowska, s. 250-256.

${ }^{48}$ ABC, Liber capitolorum localium; Dalszy poczet opatów, s. 20, 26; Łatak, Kongregacja krakowska, s. 275-278.

${ }^{49} \mathrm{P}$. Gach, Kasaty klasztorów kanoników regularnych w XIX stuleciu, w: Kanonicy regularni laterańscy w Polsce. Studia z dziejów Kongregacji Krakowskiej XV-XIX wieku, red. Z. Jakubowski, Kraków 1975, s. 90-91.

${ }^{50}$ Pierwsze drukowane kazanie w języku polskim ukazało się w 1574 roku. Była to mowa żałobna wygłoszona 12 II 1574 roku w katedrze krakowskiej przez opata cystersów w Mogile i biskupa sufragana krakowskiego Marcina Białobrzeskiego na pogrzebie króla Zygmunta Augusta. Por. W. Budka, Białobrzeski Marcin, PSB, t. 2, Kraków 1936, s. 14-15; Wolański, Kaznodziejstwo bernardyńskie, s. 76. 
w państwowych archiwach wojewódzkich i archiwach diecezjalnych, największy zasób ocalał w bibliotece i Archiwum Klasztoru Bożego Ciała w Krakowie. Ich autorstwo i proweniencja jest ciągle sprawą otwartą. Niektórych autorów trudno jest zidentyfikować. Wiele materiałów kaznodziejskich uległo zniszczeniu lub po prostu zaginęło. Być może spuścizna pisarska wielu kaznodziejów nie przedstawiała większej wartości, co mogło być powodem, że nie była właściwie przechowywana. Zachowane materiały kaznodziejskie można umownie podzielić na trzy grupy: kazania o pewnym autorstwie, teksty anonimowe kanoników regularnych, teksty pochodzące z innych bibliotek, czy archiwów kongregacji kanoników regularnych laterańskich ${ }^{51}$.

$\mathrm{W}$ porównaniu $\mathrm{z}$ innymi zakonami, szczycącymi się w swoich szeregach najwybitniejszymi kaznodziejami w Polsce, wkład kanoników regularnych laterańskich w tej dziedzinie nie jest zbyt imponujący. Nie ma ich wśród głośnych obrońców wiary katolickiej przed atakami różnowierców, nie są widoczni także w gronie kapelanów na dworach królewskich czy magnackich. Ponadto, dość późno zauważa się przedstawicieli tego zakonu pośród kaznodziei obozowych, spełniających ważną rolę w duszpasterstwie polowym i wojskowym. Prawdopodobnie do pierwszych należą dwaj księża (Kępski i Sergiusz Widoman), którzy mimo zakazu przełożonego uciekli z klasztoru i zasilili szeregi konfederatów barskich. Dopiero w powstaniu kościuszkowskim kanonicy regularni (ks. Gołoński i ks. Radecki) samowolnie podjęli obowiązki duszpasterskie. Za działalność kościelno-patriotyczną pierwszy z nich przez trzy tygodnie siedział w więzieniu, a drugi stracił życie ${ }^{52}$. Mimo to, kaznodzieje z kongregacji krakowskiej kanoników regularnych laterańskich wśród dużej liczby zakonów męskich na ziemiach Polski i Litwy zajmują poczesne miejsce. Jak już wspomniano powyżej, ich działalność niejednokrotnie wykraczała poza mury własnego opactwa czy prepozytur. W dziedzinie zasług dla kaznodziejstwa polskiego z całą odpowiedzialnością można ich umieścić bezpośrednio po jezuitach, dominikanach i bernardynach ${ }^{53}$.

$\mathrm{Z}$ danych uzyskanych z nekrologów krakowskich i poszczególnych kanonii, jak i z protokołów Kapituł Generalnych odbytych w Kazimierzu można poznać nazwiska kaznodziejów kraśnickich. W nekrologach tych każdemu kanonikowi przeznaczono osobną kartę, bez względu na obszerność tekstu. Poza datą śmierci, bądź pogrzebu, imieniem chrzcielnym i zakonnym oraz nazwiskiem, podawano w kolejności pełnione obowiązki i urzędy w poszczególnych kanoniach i prepozyturach. Przy wielu nazwiskach brak jest datacji dotyczącej sprawowania posługi kaznodziei w Kraśniku. Dotyczy to przeważnie tych kanoników, którzy zmarli $\mathrm{w}$ innych prepozyturach należących do kongregacji krakowskiej. W przeprowadzanej kwerendzie niezwykle cenne okazały się zachowane protokoły z Kapituł Generalnych odbytych w klasztorze Bożego Ciała na Kazimierzu. Sekretarze

${ }^{51}$ Wolański, Kaznodziejstwo bernardyńskie, s. 57-58.

${ }^{52}$ P.P. Gach, Zakony w powstaniu kościuszkowskim, w: Sukmana i krzyż. Studia z dziejów insurekcji kościuszkowskiej, red. J. Ziółek, Lublin 1990, s. 159-186; tenże, Zakonni kapłani wojskowi pod koniec XVIII $i$ w XIX stuleciu, w: Historia duszpasterstwa wojskowego na ziemiach polskich, red. J. Ziółek i inni, Lublin 2004, s. 242-243.

${ }^{53}$ Związek, Z dziejów kaznodziejstwa katolickiego, s. 242, 249. 
skrupulatnie spisywali nie tylko postanowienia, zalecenia czy uwagi, ale każdorazowo także skład personalny poszczególnych prepozytur. Przy poszczególnych nazwiskach dodawali pełnione przez członków danego konwentu funkcje. Jest to nieoceniony materiał nie tylko do poszukiwania kaznodziejów kraśnickich, ale i do prześledzenia fluktuacji kadry kaznodziejskiej w całej kongregacji krakowskiej. Podjęta problematyka kaznodziejska w Kongregacji Kanoników Regularnych Laterańskich oczekuje nadal na wnikliwych badaczy i rezultaty bardziej szczegółowych i obszerniejszych publikacji.

Na podstawie dostępnych materiałów archiwalnych przechowywanych w Archiwum Klasztoru Bożego Ciała w Krakowie i publikacji ks. prof. Kazimierza Łataka, udało się już ustalić, że w latach 1501-1864 posługę kaznodziejską w prepozyturze kraśnickiej pełniło 66 kanoników regularnych. Z pewnością nie jest to jeszcze pelna ich lista ${ }^{54}$.

Ks. Jan z Lublina, zmarł między 1507 a 1512 rokiem, magister atrium, a co najmniej od 1501 roku w Kraśniku, prawdopodobnie był kaznodzieją;

Ks. Jan Myslovius († 1561), wspaniały kaznodzieja;

Ks. Jan Turobinius $(1560-\uparrow 1574)$;

Ks. Marcin Nowoyski z Mielca $(1574-\uparrow 1613)$, był prepozytem w Kraśniku, przed rokiem 1594 kaznodzieją;

Ks. Jan Baptysta Malanowski (1623-1627);

Ks. Wit Wnuczkowski (1627-1634);

Ks. Jan Augustyn Biesiekierski (1631-1635);

Ks. Jan Kołacki (1635-1638);

Ks. Gaspar Kazimierz Różycki $(1638-\uparrow 1639)$;

Ks. Jakub Fulgencjusz Hasjusz (1643);

Ks. Adam Benedykt Samotulski (1650-1651);

Ks. Joachim Wyszyński (1654-1657);

Ks. Albert Zalasowicz $(\dagger 1670)$;

Ks. Grzegorz Cichoszewicz († 7 marca 1672 w Kraśniku po przeżyciu 70 lat), był przeorem i kaznodzieją, wcześniej 7 lat przebywał w niewoli tatarskiej;

Ks. Herkulan Jan Kozubski $(† 1672)$;

Ks. Augustyn Fronchold ( $\uparrow 1678)$, jego dodatkową pasją była gra na organach;

Ks. Albin Kubkowicz († 1688) w Wilnie, pełnił obowiązki kaznodziei w wielu konwentach, jednak nie ustalono, w jakich latach pracował w Kraśniku;

Ks. Jan Rudnicki (1689);

Ks. Bartłomiej Grątkowski († 26 XII 1696 w Kraśniku);

Ks. Stanisław Muszyński († $1705 \mathrm{w}$ Wilnie), przez 17 lat był kaznodzieją w różnych klasztorach, a w latach 1697-1700 w Kraśniku;

Ks. Szymon Gilbert Bielecki († 1706 w Bychowie), wybitny kaznodzieja w kilku klasztorach, a przed rokiem $1700 \mathrm{w}$ Kraśniku;

Ks. Bartłomiej Mikołaj Cynaki (1700-1703, 1706-1709);

Ks. Walenty Franciszek Wadzicki (1703-1705);

${ }^{54}$ Listę wykonano na podstawie zachowanych materiałów w ABC, ACG; Memoriale Fratrum et Benefactorum defunctorum Congregationis Canonicorum Regularium Laterainsium; Liber Defunctorum 1784-1797. 
Ks. Marcin Marceli Soliński (1703-1706), po bitwie pod Wiedniem (1683) tureckiego chłopca przywiózł magnat Pac na Litwę; śniku;

Ks. Romold (zak.) Krannich († 1707), przed 1706 rokiem kaznodzieja w Kra-

Ks. Jan Kacki (1706-1708);

Ks. Stanisław Floryd Józefowicz (1709-1712);

Ks. Jan Grąbczewski, w 1711 roku zrezygnował z urzędu prepozyta, wcześniej był kaznodzieją w Kraśniku;

Ks. Tomasz Augustyn Parkiewicz (1712-1715), doktor filozofii;

Ks. Stanisław Tomasz Klinkiewicz (1715-1719, 1744);

Ks. Gaudenty Wierduński († 1719), w 1689 roku był zatrudniony jako kaznodzieja w Kraśniku;

Ks. Mateusz Herkulan Fischer (1722);

Ks. Paweł Relowski, $(† 1722)$;

Ks. Franciszek Barański († 1724), doktor teologii, przeniesiony z Krzemienicy, prepozyt i kaznodzieja w Kraśniku;

Ks. Józef Remigiusz Palkowski (1726-1730, 1735-1738);

Ks. Jan Cerboniusz Szembek (1730-1735);

Ks. Jan Strzelecki (1738), wieloletni kaznodzieja w Kraśniku, wcześniej ksiądz diecezji krakowskiej, w której był kanonikiem wojnickim i kaznodzieją tarnowskim;

Ks. Tomasz Kwapiński († 1749 w Kraśniku);

Ks. Jan Grzegorz Alipiusz Moschner (1747-1758);

Ks. Malachiasz Stawiarski (1751-1754);

Ks. Franciszek Benedykt Rozmarynowski (1754-1758);

Ks. Błażej Zagórski (1758-1761);

Ks. Rajmund Stanisław Gembiński († 1761);

Ks. Odulf Szpiller (1761-1764);

Ks. Piotr Kocimski (1776-1777);

Ks. Michał Euzebiusz Świderski, w 1776 roku był kaznodzieją w Kraśniku;

Ks. Patryk Młynarski (1779-1781);

Ks. Norbert Lalikowski (1782), profesor filozofii;

Ks. Michał Patryk Maszczykowski (1782-1784);

Ks. Alipiusz Ząbkowski, w 1782 roku był profesorem retoryki i kaznodzieją w Kraśniku;

Ks. Jacek Abiliusz Zielonkiewicz (1761-1793), studiował w Rzymie i uzyskał doktorat z filozofii, a w Krakowie doktorat z teologii; w 1. 1785-1787 pełnił obowiązki kaznodziei i profesora filozofii w Kraśniku;

Ks. Andrzej Wilhelm Torbiński (1785);

Ks. Dominik Alipiusz Zabkowski (1784-1786);

Ks. Teotoniusz (Andrzej?) Śliwiński (1791);

Ks. Bernard Niewolski (1798);

Ks. Jan Starowicz (1803);

Ks. Wincenty Floryd Mydlarski (1803);

Ks. Tomasz Zachymski (1808); 
Ks. Jakub Brunon Wąsikiewicz (1814);

Ks. Wedasty Niewolski, brat Bernarda (1814);

Ks. Wojciech Rysiewicz (1815);

Ks. Tomasz Franciszek Madeyski (1823-1829);

Ks. Szymon Poręba (1829);

Ks. Firmian Kucharski († 1739 w Kraśniku), kaznodzieja i prepozyt;

Ks. Szymon Królikowski (1733-1777), 1861 r. kaznodzieja w Kraśniku;

Ks. Andrzej Sobański (1861-1864).

słowa kluczowe: Kraśnik; Kanonicy Regularni Laterańscy; kaznodziejstwo

\section{BIBLIOGRAFIA}

\section{Źródla}

Archiwum Klasztoru Bożego Ciała w Krakowie

ACG 1700, ACG 1703, ACG 1722, ACG 1767;

Memoriale Fratrum et Benefactorum defunctorum Congregationis Canonicorum Regularium Laterainsium; Cathalogus Fratrum definitorium.

Archiwum Klasztoru OO. Paulinów na Jasnej Górze

sygn. 254, Acta visitationum seu prepositorum Canonicorum Regularium Lateranensium;

Constitutiones Canonicorum Regularium Ordinis S. Augustini Congregationis Salvatoris Lateranensis, Romae 1628.

Dokumenty Soborów Powszechnych, oprac. A. Baron, H. Pietras, t. 1-4, Kraków 20022005.

Gorczyński M.A., Schema de Canonicis Regularibus Lateranensibus Congregationis Cracoviensis, w: Joannes de Nigro Valle, Genealogia Sacri et Apostolici Ordinis Canonicorum Regularium, Kraków 1707.

Najstarsze statuty synodalne krakowskie biskupa Nankera z 2 października 1320 r., wyd. J. Fijałek, Kraków 1915.

Łoniewski K., Żywot, sprawy y cudowne boskie wstawienie pobożnego kapłana B. Stanisława Kazimierczyka przy Krakowie na Kazimierzu Bożego Ciała kościele, Kraków 1618

\section{Opracowania}

Bieniarzówna J., Liberiusz Jacek, w: Polski Słownik Biograficzny, t. 17, Wrocław 1972, s. $282-283$.

Biesiekierski Jan (Augustyn), w: Encyklopedia wiedzy o jezuitach na ziemiach Polski i Litwy 1564-1995, oprac. L. Grzebień, Kraków 1996, s. 47.

Brzozowski M., Kaznodziejstwo i sprawa narodu. Elementy teologii wyzwolenia w kaznodziejstwie polskim XIX wieku, „Znak”, 398 (1988) s. 38-49.

Budka W., Białobrzeski Marcin, w: Polski Stownik Biograficzny, t. 2, Kraków 1936, s. $14-15$.

Błachut A., W pięćsetna rocznicę założenia klasztoru Bożego Ciała na Kazimierzu w Kra- 
kowie (1405-1905). Szkice dziejów opactwa Kanoników Regularnych Laretańskich, Kraków 1905.

Gach P.P., Kasaty klasztorów kanoników regularnych w XIX stuleciu, w: Kanonicy regularni laterańscy w Polsce. Studia z dziejów Kongregacji Krakowskiej XV-XIX wieku, red. Z. Jakubowski, Kraków 1975, s. 90-91.

Grzebień L., Mandziuk J., Biesiekierski Jan Augustyn, w: Słownik Polskich Teologów Katolickich, t. 1, Warszawa 1981, s. 147.

Jougan A., Homilie polskie od czasów najdawniejszych aż po dobę obecna, Lwów 1902.

Kliszko Z., Przepisy synodalne w Polsce średniowiecznej o kaznodziejstwie, „Studia Theologica Varsaviensia", 13 (1975) nr 1, s. 11-142.

Łatak K., Kanonicy regularni laterańscy na Kazimierzu w Krakowie do końca XVI wieku, Ełk 1999.

Łatak K., Kongregacja krakowska kanoników regularnych laterańskich na przestrzeni dziejów, Kraków 2002.

Łatak K., Ksiadz Stefan Ranatowicz CRL (1617-1694). Barokowy kronikarz i pisarz klasztorny, Kraków 2010.

Łatak K., Nalbach S., Ze studiów nad kultura umystową kanoników regularnych krakowskiej prepozytury Bożego Ciała w XV i XVI wieku, Kraków 2009.

Łatak K., Poczet rządców opactwa Bożego Ciała Kanoników Regularnych Laterańskich w Krakowie, Kraków 2005.

Makarczyk I., Procesy informacyjne biskupów polskich z zakonu kanoników regularnych laretańskich, w: Przemijanie i trwanie. Kanonicy Regularni Laterańscy w dawnej i współczesnej Polsce, red. K. Łatak, I. Makarczyk, Kraków [2008], s. 233-264.

Martuszewski W., Archiwalia dotyczace polskich kanoników regularnych laterańskich w Archiwum Generalnym Zakonu w Rzymie, w: Przemijanie i trwanie. Kanonicy Regularni Laterańscy $w$ dawnej $i$ współczesnej Polsce, red. K. Latak, I. Makarczyk, Kraków [2008], s. 309-318.

Ozorowski E., Liberiusz (Liberius) Jacek, w: Słownik Polskich Teologów Katolickich, t. 2, Warszawa 1982, s. 524-525.

Ozorowski E., Pukal Pawet, w: Słownik Polskich Teologów Katolickich, t. 3, Warszawa 1982, s. 460-461.

Pacevićius A., Kanonickie marginalia i proweniencje $w$ zbiorach bibliotecznych Litwy, w: Przemijanie i trwanie. Kanonicy Regularni Laterańscy $w$ dawnej $i$ wspótczesnej Polsce, red. K. Łatak, I. Makarczyk, Kraków [2008], s 403-410.

Panuś K., Historia kaznodziejstwa, Kraków 2007.

Panuś K., Kaznodziejstwo w katedrze krakowskiej, cz. 1: Od początków do czasów rozbiorów, Kraków 1995.

Panuś K., Zarys historii kaznodziejstwa w Kościele katolickim, cz. 2, Kraków 2001.

Pazera W., Kaznodziejstwo w Polsce od poczatku do końca epoki baroku, Częstochowa 1999.

Rechowicz M., Początki i rozwój kultury scholastycznej (do końca XIV wieku), w: Dzieje teologii katolickiej w Polsce, red. M. Rechowicz, t. 1, Lublin 1974, s. 17-92.

Rubin W., Lud w polskim ustawodawstwie synodalnym do rozbiorów Polski, Rzym 1955. Siwek G., Misje ludowe w teorii i praktyce Kościoła, Kraków 1999.

Skrzyniarz R., Zbiory kazań w polskich księgozbiorach okresu średniowiecza, „Archiwa, Biblioteki i Muzea Kościelne”, 70 (1998) s. 249-253.

Sroka A.B., Prawo i życie polskich reformatów, Kraków 1975.

Subera I., Synody prowincjonalne arcybiskupów gnieźnieńskich, Warszawa 1971. 
Szetelnicki W., Kaznodziejstwo polskie XVI i XVII wieku w obronie ludu, „Nasza Przeszłość", 37 (1972) s. 49-98.

Targosz K., Biogramowy wykaz osób występujacych w metryce, w: Archiwum nacji polskiej w Uniwersytecie Padewskim, t. 1, Wrocław 1971, s. 362-363.

Uruski S., Rodzina herbarz szlachty polskiej, t. 1, Warszawa 1904.

Wojtyska H.D., Nauka i nauczanie u kanoników regularnych (na przykładzie kongregacji Bożego Ciała), w: Dzieje teologii katolickiej w Polsce, red. M. Rechowicz, t. 2, cz. 2 , Lublin 1975.

Wolański F., Kaznodziejstwo bernardyńskie w staropolskim systemie komunikacji społecznej schytku epoki saskiej. Studium kształtowania wyobraźni i postaw, Toruń 2012.

Wolny J., Kaznodziejstwo, w: Dzieje teologii katolickiej w Polsce, t. 1: Średniowiecze, red. M. Rechowicz, Lublin 1974, s. 273-308.

Zielińska E., Kultura intelektualna kanoników regularnych z klasztoru w Kraśniku w latach 1469-1563, Lublin 2002.

Zieliński Z., Kościół i naród w niewoli, Lublin 1995.

Związek J., Katolickie poglady polityczno-społeczne w Polsce na przełomie XVI i XVII wieku w świetle kazań, Lublin 1977.

Związek J., Z dziejów kaznodziejstwa katolickiego w Polsce na przełomie XVI i XVII wie$k u$, „Analecta Cracoviensia”, 23 (1991) s. 427-466.

Śrutwa J., Oświecenie w Polsce i jego wpływ na życie kościelne, w: Historia Kościoła w Polsce, t. 2, cz. 1, red. B. Kumor, Z. Obertyński, Warszawa-Poznań 1979, s. 19-37.

\title{
ARS PREDICANDI. OUTSTANDING PREACHERS OF THE MONASTERY IN KRAŚNIK
}

\begin{abstract}
Summary
The article presents an outline of the issues connected with the Canons Regular preaching, including the profiles of the most outstanding preachers and the topics covered in their sermons. The study of the achievements of the Canons Regular preachers led to the conclusion that, in comparison with other religious orders boasting the most outstanding preachers in their ranks in Poland, the contribution of the Canons Regular of Lateral in this field is not very impressive. They are not among the well-known defenders of the Catholic faith against the attacks of the dissenters, they are not seen among the chaplains at royal or magnate courts either. In addition, the representatives of this order are noticed quite late among the camp's preachers who played an important role in the military pastoral care. Nevertheless, preachers from the Cracow congregation of the Canons Regular occupied a prominent place among a large number of male orders in the lands of Poland and Lithuania. They were frequently active outside their own abbey or provostries.
\end{abstract}

Keywords: preachers; sermons; the Canons Regular; Kraśnik 